\title{
PENERAPAN METODE MONTE CARLO PADA PENJADWALAN PROYEK SERPONG GARDEN APARTMENT
}

\author{
Felix Septian Wijaya ${ }^{1}$ dan Hendrik Sulistio ${ }^{2}$ \\ ${ }^{1}$ Program Studi Sarjana Teknik Sipil, Universitas Tarumanagara, Jl.Letjen S. Parman No.1 Jakarta \\ Email: felixseptianw@gmail.com.ac.id \\ ${ }^{2}$ Program Studi Sarjana Teknik Sipil, Universitas Tarumanagara, Jl.Letjen S. Parman No.1 Jakarta \\ Email: hendrikdtsundip@gmail.com
}

\begin{abstract}
ABSTRAK
Proyek konstruksi selalu penuh dengan ketidakpastian, misalnya dalam hal ketidakpastian waktu penyelesaian, yang dapat menyebabkan risiko kerugian baik bagi kontraktor maupun pemilik proyek. Untuk meminimalkan dampak risiko tersebut, telah dikembangkan metode penjadwalan dengan mempergunakan durasi probabilistik salah satunya adalah Metode Monte Carlo. Pada penelitian ini dilakukan simulasi Monte Carlo dengan berdasarkan durasi pekerjaan optimis, paling disukai, dan pesimis hasil survei pada pihak kontraktor Serpong Garden Apartement. Simulasi pada skripsi ini menggunakan software Crystal Ball dan distribusi data yang digunakan adalah distribusi triangular. Setelah dilakukan simulasi ini selanjutnya akan di analisis dan dibandingkan dengan jadwal durasi rencana, optimis, paling disukai, dan pesimis. Perbedaan jadwal yang di analisis dan di bandingkan adalah durasi akhir proyek dan besar probabilitas selesainya sesuai dengan jadwal.Hasil dari perbandingan jadwal yang dilakukan pada skripsi ini terdapat perbedaan penjadwalan pada durasi akhir yakni durasi optimis selama 80 minggu, durasi paling disukai selama 114 minggu, durasi pesimis selama 157 minggu, dan durasi hasil simulasi selama 123 minggu. Perbedaan jadwal pada proyek Serpong Garden Apartement bila dibandingkan dengan penjadwalan menggunakan metode Monte Carlo adalah lama durasi dan besar probabilitas penyelesaian proyek. Lama durasi jadwal rencana selama 121 minggu dengan probabilitas sebesar 37.16\%. Sedangkan durasi hasil metode Monte Carlo selama 123 minggu dengan probabilitas sebesar 48.32\%.
\end{abstract}

Kata kunci: Monte Carlo, durasi, penjadwalan, probabilitas

\section{PENDAHULUAN}

Proyek konstruksi selalu penuh dengan ketidakpastian (uncertainty), misalnya dalam hal ketidakpastian waktu penyelesaian, yang dapat menyebabkan risiko kerugian baik bagi kontraktor maupun pemilik proyek (owner). Untuk meminimalkan dampak risiko tersebut, perlu alat (tools) untuk menganalisisnya.

Untuk mengantisipasi ketidakpastian pada estimasi durasi dan rencana biaya sebuah proyek konstruksi, maka telah dikembangkan metode yang dapat mempertimbangkan ketidakpastian yang dimungkinkan dapat terjadi dalam pelaksanaan suatu kegiatan proyek. Salah satu cara untuk mempertimbangkan ketidakpastian dalam durasi sebuah proyek ialah dengan menganalisis penjadwalan tersebut dengan metode probabilistik. Metode penjadwalan probabilistik yang bisa digunakan salah satunya adalah metode Monte Carlo.

\section{Manajemen Proyek}

Manajemen proyek merupakan suatu usaha meliputi merencanakan, mengorganisir, mengarahkan, mengkoordinasi, dan mengawasi kegiatan dalam sebuah proyek dengan sedemikian rupa sehingga sesuai dengan jadwal waktu dan anggaran yang telah ditetapkan. Manajemen proyek konstruksi ialah penerapan fungsi-fungsi manajemen pada suatu proyek dengan menggunakan sumber daya efektif dan efisien agar tujuan dapat tercapai. Menurut Ervianto (2002), Manajemen konstruksi meliputi cara bagaimana agar sumber daya yang terlibat dapat diaplikasikan oleh manajer proyek secara tepat. Sumber daya yang dimaksud disini ialah meliputi manpower, material, machine, money, dan method. 


\section{Proyek}

Proyek merupakan suatu kegiatan kongkret yang dilakukan untuk mencapai hasil akhir dan harus diselesaikan dalam kurun waktu tertentu dengan menggunakan sumber daya terbatas. Menurut Syah (2004) proyek adalah suatu rangkaian kegiatan yang terencana dan dilaksanakan secara berurutan serta menggunakan banyak jenis sumberdaya dan dibatasi oleh biaya, mutu, dan waktu. Tujuan dari kegiatan proyek ialah untuk mewujudkan gagasan yang timbul dari naluri manusia. Sehingga dapat dikatakan bahwa suatu proyek memiliki sifat dan ciri yang khas dan berbeda dengan aktivitas lainnya.

\section{Manajemen Waktu Proyek}

Waktu pelaksanaan proyek adalah bagian dari rencana proyek yang berisikan perkiraan waktu untuk menyelesaikan setiap pekerjaan. Manajemen waktu dalam sebuah proyek merupakan bagian yang sangat penting dalam penyelesaian dan pengendalian proyek. Keberhasilan dalam sebuah proyek akan ditentukan apabila waktu penyelesaian proyek lebih kecil daripada waktu yang direncanakan. Apabila waktu penyelesaian lebih besar dibandingkan waktu rencana, maka proyek tersebut dapat dikatakan terlambat.

\section{Diagram Balok (Bar Chart)}

Diagaram balok mula-mula diperkenalkan oleh Hendri Lawrence Gantt pada tahun 1917. Diagram balok merupakan bagan balok dengan panjang balok digunakan sebagai durasi kegiatan. Diagram ini bertujuan untuk mengidentifikasi waktu dan urutan pengerjaan kegiatan yang terdiri dari waktu mulai, waktu selesai, dan pelaporan. Diagram batang secara sederhana dapat menunjukkan informasi rencana jadwal proyek dan durasinya yang kemudian dibandingkan dengan progres sebenarnya sehingga diketahui proyek tersebut tepat waktu atau tidak.

\section{Kurva S}

Kurva S adalah suatu grafik hubungan antara waktu pelaksanan proyek dengan nilai akumulasi progres yang telah dicapai proyek tersebut. Bisa dikatakan kurva S merupakan metode perencanaan dan kendali waktu paling populer dalam monitoring pelaksanaan proyek. Hampir semua proyek, baik pemerintah maupun swasta, telah lama menggunakan metode ini. Pada awalnya, grafik kurva S dkembangkan oleh Jendral Warren Hannum. Di dalam pengaplikasiannya, kurva S dapat digunakan sebagai: Pengarah penilaian atas progres pekerjaan, Pada permulaan kegiatan menunjukkan progras yang kecil. Maka, rencana juga harus sesuai dengan kemampuan dan kondisi persiapan pekerjaan, dan membantu seorang perencana proyek. Suatu proyek umumnya dimulai dengan rencana program yang kecil dan kemudian meningkat pada beberapa waktu kemudian. Kurva S dapat berfungsi sebagai pengkoreksi jadwal yang telah dibuat.

\section{Metode Monte Carlo}

Simulasi Monte Carlo adalah sebuah metode analisis yang didasarkan dengan nilai data-data acak yang melahirkan sebuah statistik probabilitas yang selanjutnya digunakan untuk memahami dampak dari sebuah ketidakpastian. Penggunaan Monte Carlo sendiri sudah sangat berkembang dalam bidang evaluasi proyek, manajemen proyek, analisis biaya, dan lainnya. Menurut Widya (2017), simulasi Monte Carlo merupakan simulasi tipe probabilitas yang mendekati solusi sebuah masalah dengan melakukan sampling dari proses acak. Selanjutnya setiap variabel dalam model tersebut memiliki nilai yang memiliki probabilitas yang berbeda, yang ditunjukkan oleh distribusi probabilitas dari setiap variabel. Monte Carlo mengsimulasikan sistem tersebut berulang kali bahkan sampai ribuan kali tergantung sistem yang ditinjau, dengan cara memilih nilai random untuk tiap variabel dari distribusi probabilitasnya. Metode penjadwalan yang umum digunakan yaitu metode CPM (Critical Path Method) ataupun PDM (Precedence Diagram Method). Namun kedua metode tersebut kurang akurat apabila diaplikasikan karena metode tersebut mengestimasikan durasi proyek secara pasti. Padahal di dunia nyata, pekerjaan proyek merupakan pekerjaan dengan resiko ketidakpastian yang tinggi. Maka dari itu, simulasi Monte Carlo dapat menjadi jawaban atas permasalahan ketidakpastian dalam pekerjaan proyek. Keuntungan penggunaan simulasi Monte Carlo ini ialah simulasi ini merupakan perangkat yang cermat dalam menganalisa kemungkinan ketidakpastian yang sering terjadi di dalam proyek. Dengan adanya keuntungan tersebut, diharapkan dapat menjadikan proyek meminimalisir risiko ketidakpastian agar dapat berjalan dengan optimal baik di sisi waktu, sumber daya, maupun biaya. Dengan keuntungan besar dari simulasi ini untuk optimalnya sebuah proyek, namun dalam praktiknya metode ini belum banyak digunakan. Hal tersebut dikarenakan karena kurangnya pemahaman terhadap statistika dan metode Monte Carlo. Banyak yang menganggap metode ini sebagai beban karena kurangnya pemahaman tersebut. 


\section{METODOLOGI PENELITIAN}

Pada penelitian ini, dilakukan simulasi pemodelan penjadwalan ke dalam software Oracle Crystal Ball, dan akan mendapatkan hasil durasi dengan menggunakan metode Monte Carlo.

\section{Deskripsi Umum Proyek}

Nama Proyek

Kontraktor Proyek

Spesifikasi Umum

Nilai Proyek

Tipe Kontrak

Durasi proyek
: Serpong Garden Apartment

: CSCEC-MEGAKON-DU JO

: 2 Tower dengan banyak lantai masing-masing tower adalah 27 lantai

: \pm 397 Miliar Rupiah

: Lumpsum

: 29 Januari 2018 - 7 Juli 2020

\section{Tahapan Penelitian}

a) Pembuatan kuesioner

Kuesioner yang dibuat bertujuan untuk mengetahui durasi minimum ,yang paling disukai, dan maksimum pada masing-masing pekerjaan.

b) Pengisian kuesioner dan wawancara

Kuesioner yang telah dibuat akan diberikan kepada stakeholder dan juga pekerja yang turut andil dalam proses pembangunan gedung untuk dilakukan pengisian. Pengisian kuesioner berupa durasi setiap pekerjaan dilakukan berdasarkan pengalaman-pengalaman selama bekerja di lapangan. Selain kuesioner dilakukan juga kegiatan wawancara untuk menambah referensi bagi pengerjaan skripsi.

c) Input data dan melakukan simulasi Monte Carlo Input data dan simulasi Monte Carlo dilakukan setelah data durasi minimum, most likely, dan maksimum telah didapatkan. Simulasi dilakukan dengan menggunakan software Crystal ball.

d) Didapatkan hasil simulasi Monte Carlo terhadap durasi pekerjaan proyek.

e) Analisis data

Analisis yang dilakukan untuk mengetahui durasi akhir proyek dan probabilitas keberhasilan durasi tersebut.

f) Kesimpulan dan Saran

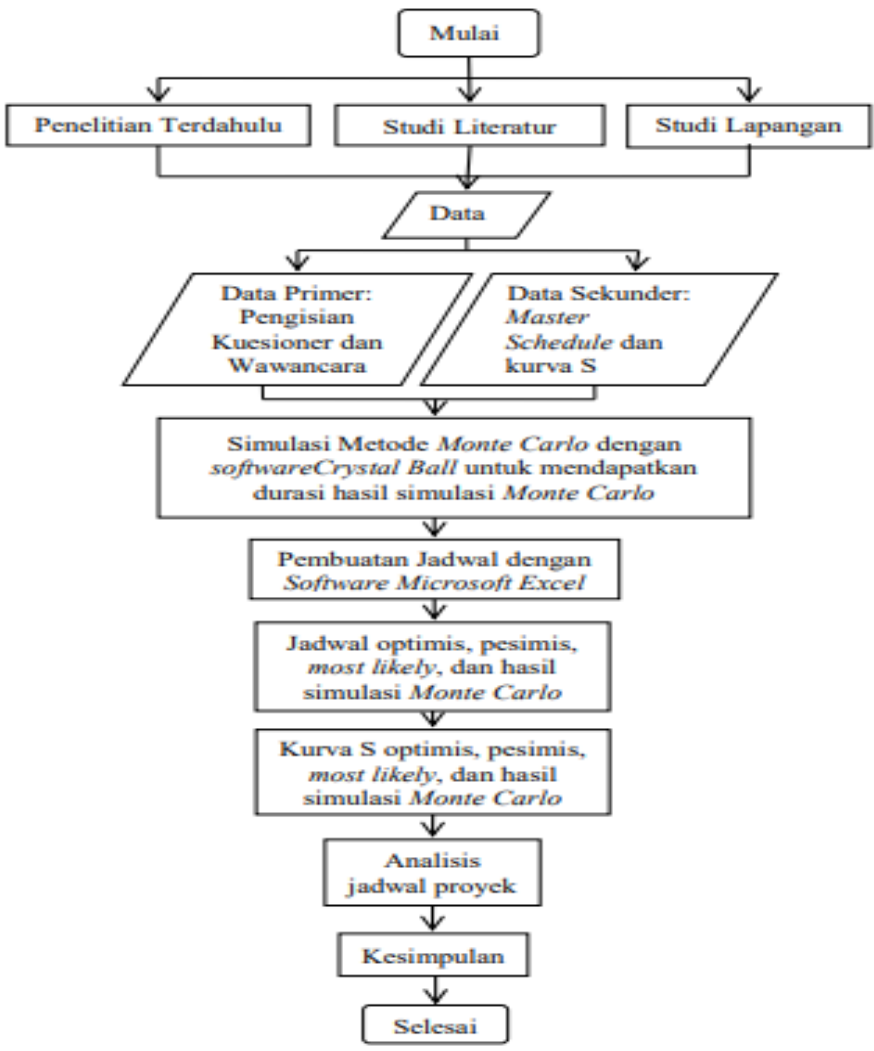

Gambar 1. Diagram Alir 


\section{PENGOLAHAN DATA DAN ANALISIS}

\section{Network Planning}

Dalam penelitan ini kegiatan-kegiatan dalam proyek disederhanakan. Item-item kegiatan dikelompokkan menjadi paket-paket kegiatan, dengan tidak mengurangi keakuratan hasil analisis yang dihasilkan. Adapun paket-paket kegiatan tersebut dibagi menjadi sebagai berikut: Persiapan, Tanah, Struktur Bawah, Struktur Atas, Dinding dan Partisi, Pintu dan Jendela, Lantai, Plafond, Sanitasi, Pelengkap/lain-lain, MEP (Mekanikal, Elektrikal dan Plumbing).

Setelah itu, paket-paket kegiatan tersebut akan dihubungkan sesuai dengan keterkaitannya sesuai dengan Gambar 2. Lalu, dengan durasi yang didapat dari kontraktor pelaksana dapat dihitung waktu mulai tercepat, waktu mulai terlama, waktu selesai tercepat dan waktu selesai terlama. Perhitungan tersebut juga menghasilkan waktu penyelesaian keseluruhan proyek. Waktu Penyelesaian Proyek yang direncanakan oleh kontraktor pelaksana adalah 121 minggu.

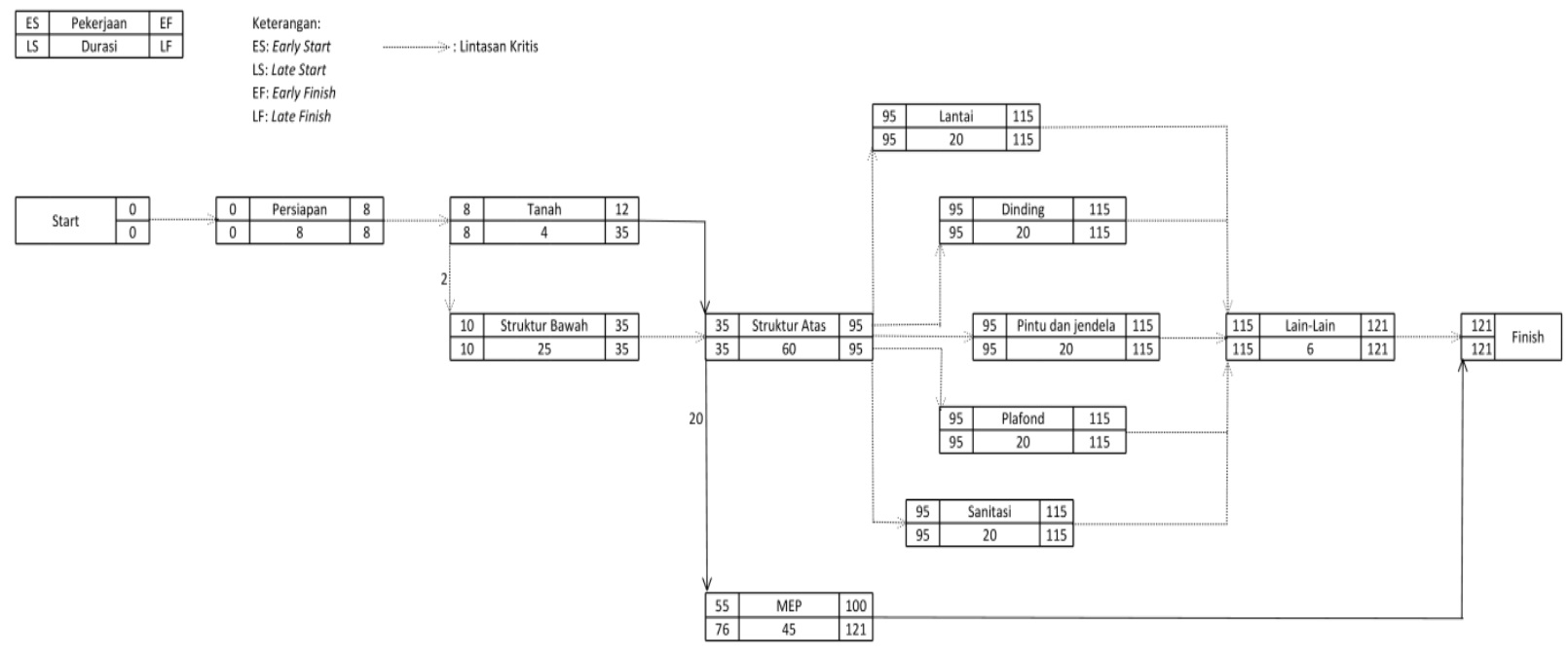

Gambar 2. Network Planning

\section{Simulasi Monte Carlo}

Untuk membandingkan durasi yang sudah direncanakan oleh kontraktor pelaksana maka metode Monte Carlo ini dilakukan. Dalam melakukan metode Monte Carlo ini diperlukan 3 parameter durasi yaitu durasi optimis, most likely, dan pesimis. Ketiga parameter durasi tersebut didapatkan dengan cara pengisian kuesioner dan kegiatan wawancara kepada orang-orang yang terlibat dalam pembangunan proyek tersebut. Kuesioner dan hasil wawancara tersebut dianalisis dengan statistika deskriptif dengan jawaban kuesioner yang berupa hari diubah kedalam minggu dimana satu minggu terdiri dari 7 hari kerja efektif. Berdasarkan analisis hasil pengisian kuesioner dan kegiatan wawancara didapatkan hasil sebagai berikut:

Tabel 1. Tabulasi Durasi Kegiatan Metode Monte Carlo

\begin{tabular}{|c|c|c|c|}
\hline Kegiatan & $\begin{array}{l}\text { Durasi } \\
\text { Optimis } \\
\text { (Minggu) }\end{array}$ & $\begin{array}{l}\text { Durasi } \\
\text { Most } \\
\text { Likely } \\
\text { (Minggu) }\end{array}$ & $\begin{array}{l}\text { Durasi } \\
\text { Pesimis } \\
\text { (Minggu) }\end{array}$ \\
\hline Persiapan & 4 & 5 & 9 \\
\hline Tanah & 4 & 6 & 9 \\
\hline Struktur Bawah & 15 & 25 & 36 \\
\hline Struktur Atas & 46 & 48 & 57 \\
\hline $\begin{array}{l}\text { Dinding dan } \\
\text { Partisi }\end{array}$ & 11 & 30 & 45 \\
\hline Pintu dan Jendela & 11 & 30 & 45 \\
\hline
\end{tabular}


Tabel 1. Tabulasi Durasi Kegiatan Metode Monte Carlo (Lanjutan)

\begin{tabular}{llll}
\hline \multicolumn{1}{c}{ Kegiatan } & $\begin{array}{l}\text { Durasi } \\
\text { Optimis } \\
\text { (Minggu) }\end{array}$ & $\begin{array}{l}\text { Durasi } \\
\text { Most } \\
\text { Likely } \\
\text { (Minggu) }\end{array}$ & $\begin{array}{l}\text { Durasi } \\
\text { Pesimis } \\
\text { (Minggu) }\end{array}$ \\
\hline Lantai & 7 & 22 & 37 \\
\hline Plafond & 7 & 22 & 37 \\
\hline Sanitasi & 11 & 30 & 45 \\
\hline Pelengkap/lain2 & 2 & 4 & 8 \\
\hline MEP & 33 & 34 & 36 \\
\hline
\end{tabular}

Setelah didapatkan parameter yang dibutuhkan, dilakukan simulasi Monte Carlo dengan bantuan software Crystal Ball. Adapun tahapan simulasi sebagai berikut:

1. Menginput item-item pekerjaan kedalam excel.

2. Menjadikan cell durasi sebagai cell assumption dengan menuliskan durasi yang paling disukai didalam cell tersebut lalu mengklik define assumption pada toolbar software Crystal Ball lalu pilih Triangular. Setelah itu masukan durasi optimis/minimum durasi, most likely,dan pesimis/maksimum pada kotak yang tersedia. Jika berhasil maka secara otomatis cell tersebut akan berwarna hijau. Lakukan langkah ini pada setiap durasi masing-masing pekerjaan.

3. Menentukan jumlah iterasi yang digunakan dalam metode Monte Carlo ini. Klik menu run preferences lalu mengganti angka pada kotak yang tersedia. Dalam skripsi ini digunakan iterasi sebanyak 10.000 kali.

4. Menjadikan cell titik akhir/finish sebagai cell Forecast. Dengan mengklik cell yang akan dijadikan cell Forecast lalu mengklik Define Forecast pada toolbar softwareCrystal Ball. Jika berhasil maka secara otomatis cell tersebut akan berwarna biru muda.

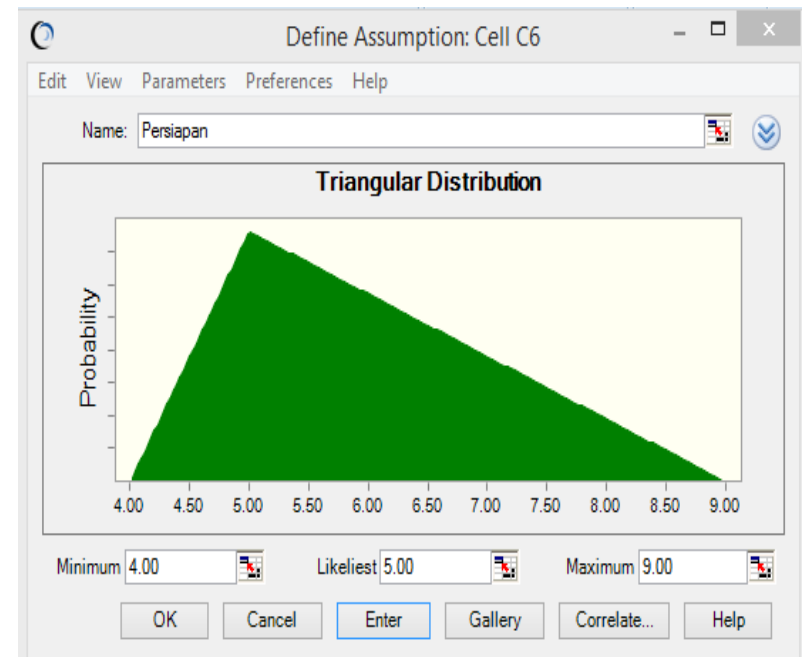

Gambar 3. Triangular Distribution pada Crystal Ball

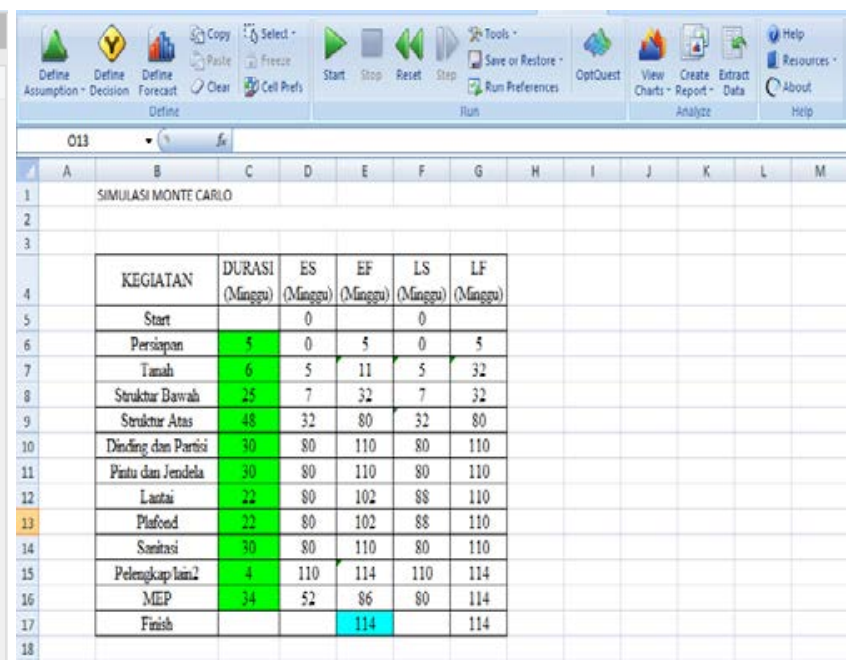

Gambar 4. Tahapan Simulasi Monte Carlo

Setelah melakukan tahapan simulasi, maka didapatkan hasil berupa durasi hasil Metode Monte carlo (Gambar 5) dan juga grafik probabilitas/kemungkinan keberhasilan durasi tersebut dapat terlaksana (Gambar 6). Dari simulasi Monte Carlo didapatkan hasil yakni waktu penyelesaian proyek selama 123 Minggu. 


\begin{tabular}{|l|r|}
\hline \multicolumn{1}{|c|}{ Statistic } & Forecast values \\
\hline Trials & 10,000 \\
\hline Mean & 123.31 \\
\hline Median & 123.28 \\
\hline Mode & $\ldots$. \\
\hline Standard Deviation & 6.79 \\
\hline Variance & 46.11 \\
\hline Skewness & 0.0202 \\
\hline Kurtosis & 2.81 \\
\hline Coeff. of Variability & 0.0551 \\
\hline Minimum & 97.61 \\
Maximum & 147.69 \\
\hline Mean Std. Error & 0.07 \\
\hline
\end{tabular}

Gambar 5. Statistik Deskriptif

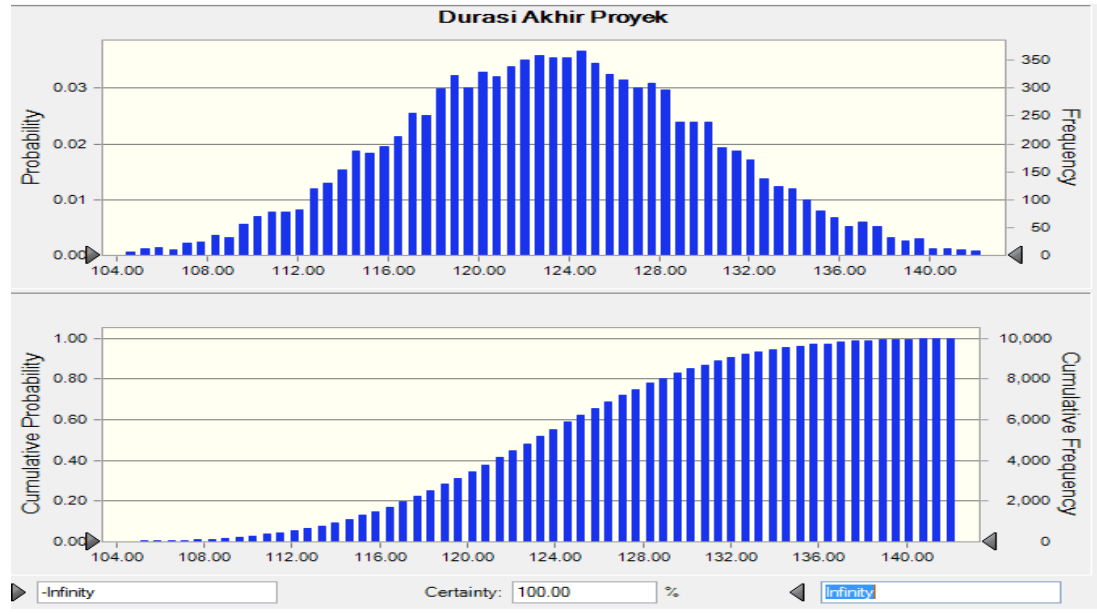

Gambar 6. Grafik Frekuensi dan Frekuensi Kumulatif

\section{Analisis Jadwal Proyek}

Dari hasil penjadwalan didapatkan empat macam kurva S yakni durasi optimis, paling disukai, pesimis, dan hasil simulasi yang selanjutnya dibandingkan dengan kurva S rencana proyek. Berikut adalah perbandingan kurva S proyek dari hasil simulasi.

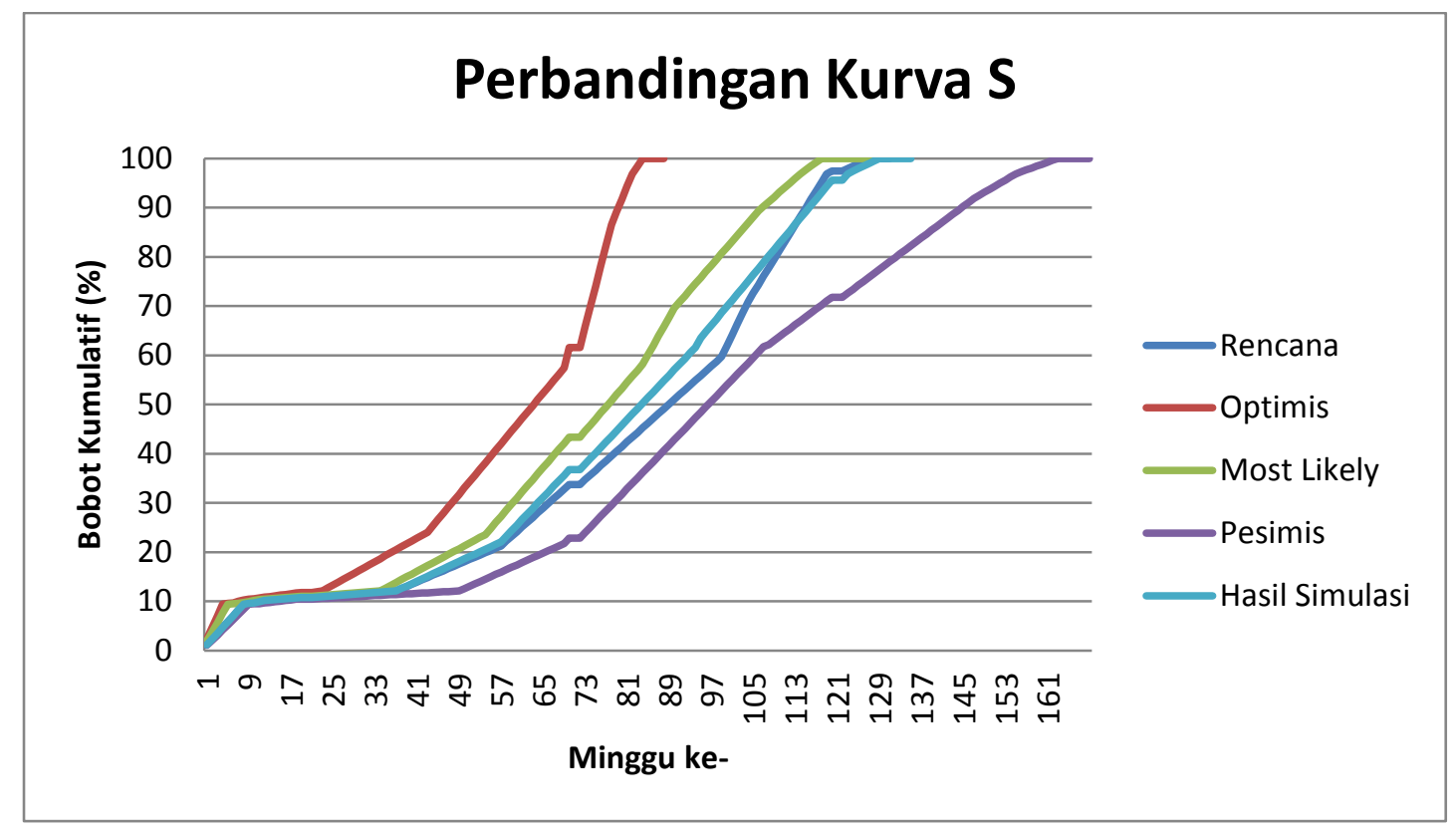

Gambar 7. Perbandingan Kurva S Rencana dan Hasil Simulasi

Tabel 2. Total Durasi Penjadwalan

\begin{tabular}{lccccc}
\hline \multicolumn{1}{c}{ Jadwal } & Rencana & Optimis & Most Likely & Pesimis & $\begin{array}{c}\text { Hasil } \\
\text { Simulasi }\end{array}$ \\
\hline $\begin{array}{l}\text { Durasi } \\
\text { (Minggu) }\end{array}$ & 121 & 80 & 114 & 157 & 123 \\
\hline
\end{tabular}

Dari Gambar 7 Perbandingan Kurva S Rencana dan Hasil Simulasi dan Tabel 2 Total Durasi Penjadwalan dapat dilihat bahwa jadwal rencana berada diantara durasi optimis dan durasi pesimis. Sehingga perencana atau kontraktor 
telah memperhitungkan durasi yang aman untuk proyek tersebut. Sedangkan durasi hasil simulasi Monte Carlo dapat dipertimbangkan sebagai jadwal yang lebih ideal, dikarenakan jadwal tersebut berada diantara durasi most likelydan durasi pesimis. Sehingga jadwal tersebut lebih aman untuk digunakan dan probabilitasnya lebih besar.

Dari hasil simulasi menggunakan software Crystal Ball telah diketahuiprobabilitas penyelesaian pekerjaan proyek hasil simulasi Monte Carlo tiap pekerjaan yang telah disusun menjadi jadwal pada software Microsoft Excel menghasilkan durasi selama 123 minggu dengan probabilitas sebesar 48.32\%. Jadwal dari hasil simulasi memiliki probabilitas yang lebih besar bila di bandingkan dengan jadwal rencana yang memiliki durasi selama 121 hari dengan probabilitas sebesar 37.19\%. Untuk memperbesar probabilitas selesainya proyek sesuai jadwal dan menghindari risiko yang tidak diinginkan pada kelangsungan proyek. Hendaknya dapat diperhitungkan lebih baik lagi untuk perencanaan jadwal proyek.

\section{Probabilitas Penjadwalan}

Pada Tabel 3, dilihat bahwa durasi yang direncanakan oleh kontraktor yaitu selama 121 minggu mempunyai probabilitas keberhasilan sebesar 37.19\%, untuk durasi optimis selama 80 minggu probabilitasnya sebesar $0 \%$, untuk durasi most likely selama 114 minggu probabilitasnya sebesar 9.1\%, untuk durasi pesimis selama 160 minggu probabilitasnya sebesar 100\%, dan untuk durasi dari hasil simulasi Monte Carlo selama 123 minggu dengan probabilitas sebesar $48.32 \%$.

Tabel 3. Probabilitas Durasi Penyelesaian Proyek

\begin{tabular}{ccc}
\hline Jadwal & Durasi (Minggu) & Probabilitas \\
\hline Rencana & 121 & $37.16 \%$ \\
\hline Optimis & 80 & $0 \%$ \\
\hline Most Likely & 114 & $9.1 \%$ \\
\hline Pesimis & 157 & $100 \%$ \\
\hline Hasil Simulasi & 123 & $48.32 \%$ \\
\hline
\end{tabular}

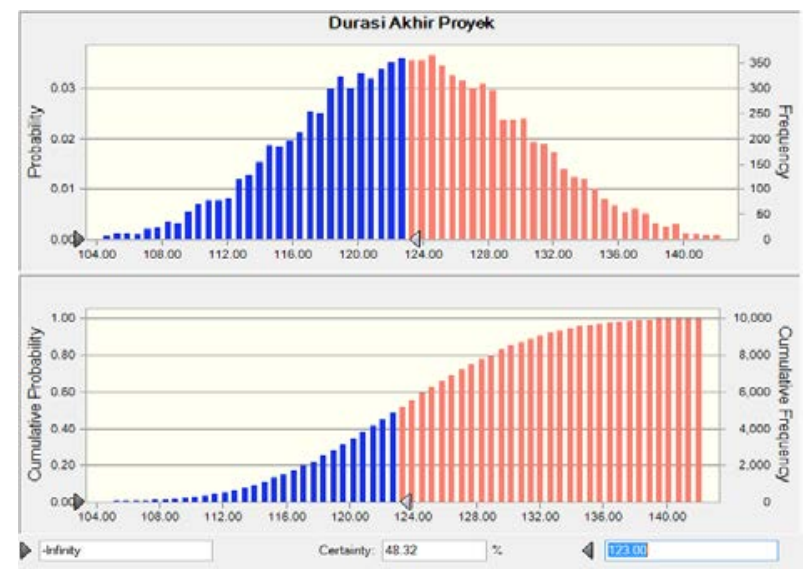

Gambar 8. Probabilitas Untuk Durasi Hasil Simulasi

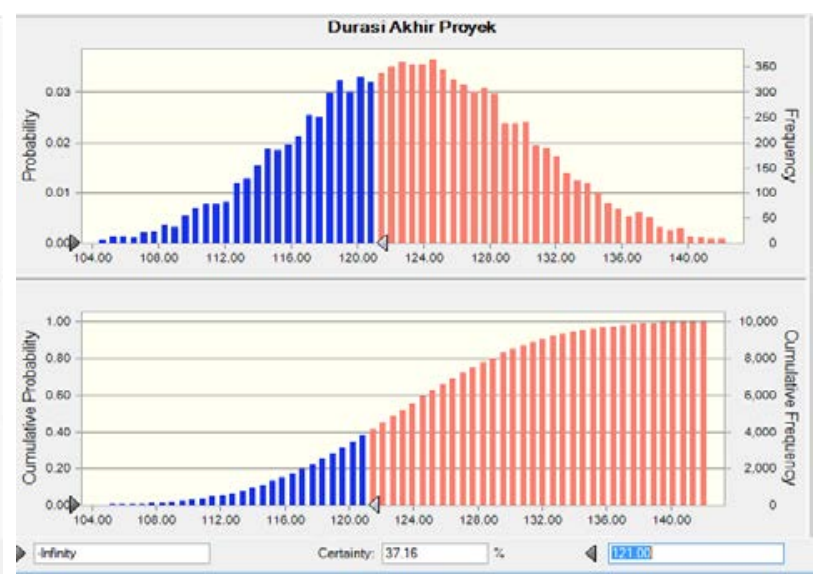

Gambar 9. Probabilitas Untuk Durasi Rencana

Pada Tabel 4, tersedia berbagai alternatif waktu penyelesaian proyek beserta dengan prosentase probabilitas keberhasilannya. Prosentase keberhasilan 1\% dengan durasi akhir selama 107.68 minggu, prosentase kerberhasilan 50\% selama 123.8 minggu, dan prosentase keberhasilan 99\% selama 138.58 minggu. Alternatif waktu penyelesaian proyek ini merupakan hasil dari metode Monte Carlo yang dapat digunakan kontraktor pelaksana proyek sebagai bahan pertimbangan untuk menghindari risiko ketidakpastian. Dimana semakin besar probabilitas keberhasilannya maka semakin bisa terlaksanakan. 
Tabel 4. Probabilitas Durasi Penyelesaian Proyek

\begin{tabular}{cccc}
\hline Probabilitas & $\begin{array}{c}\text { Durasi } \\
\text { (Minggu) }\end{array}$ & Probabilitas & $\begin{array}{c}\text { Durasi } \\
\text { (Minggu) }\end{array}$ \\
\hline $1 \%$ & 107.68 & $55 \%$ & 124.1 \\
\hline $10 \%$ & 114.33 & $60 \%$ & 125.02 \\
\hline $15 \%$ & 116.02 & $65 \%$ & 125.92 \\
\hline $20 \%$ & 117.28 & $70 \%$ & 126.89 \\
\hline $25 \%$ & 118.37 & $75 \%$ & 127.88 \\
\hline $30 \%$ & 119.46 & $80 \%$ & 129.08 \\
\hline $35 \%$ & 120.45 & $85 \%$ & 130.36 \\
\hline $40 \%$ & 121.41 & $90 \%$ & 132.13 \\
\hline $45 \%$ & 122.33 & $95 \%$ & 134.54 \\
\hline $50 \%$ & 123.18 & $99 \%$ & 138.58 \\
\hline
\end{tabular}

\section{KESIMPULAN DAN SARAN}

\section{Kesimpulan}

Berdasarkan hasil analisis melalui penerapan metode Monte Carlo didapat kesimpulan sebagai berikut:

1. Penjadwalan pada proyek Serpong Garden Apartment sudah mempertimbangkan waktu yang aman karena jadwal rencana berada diantara jadwal optimis dan pesimis. Total durasi pekerjaan dari penjadwalan optimis selama 80 minggu dan penjadwalan pesimis selama 157 minggu. Sedangkan total durasi rencana selama 121 minggu.

2. Metode Monte Carlo dapat diterapkan pada penjadwalan proyek Serpong Garden Apartment dengan cara melakukan simulasi Monte Carlo dari data durasi optimis, most likely dan pesimis. Hasil penerapan metode Monte Carlo pada penjadwalan pada proyek dapat mengetahui total durasi dari waktu simulasi Monte Carlo yaitu selama 123 minggu dan dapat mengetahui probabilitas terlaksananya pekerjaan sesuai dengan jadwal yaitu sebesar $48.32 \%$.

3. Terdapat perbedaan penjadwalan pada total durasi pekerjaan dan juga besarnya probabilitas yakni durasi rencana proyek selama 121 minggu dengan probabilitas 37.16\%, durasi optimis selama 80 minggu dengan probabilitas $0 \%$, durasi most likely selama 114 minggu dengan probabilitas 9.31\%, durasi pesimis selama 157 minggudengan probabilitas $100 \%$ dan durasi hasil simulasi Monte Carlo selama 123 minggu dengan probabilitas $48.32 \%$.

\section{Saran}

Berdasarkan hasil analisis yang dilakukan, maka saran yang dapat diberikan penulis yaitu:

1. Dalam melakukan pengisian kuesioner sebaiknya dilakukan pengisian secara langsung (tidak diberi waktu pengembalian) agar semua kuesioner yang disebarkan akan kembali juga.

2. Sebaiknya para perencana atau kontraktor untuk memiliki estimasi durasi optimis, most likely dan pesimis selain jadwal rencana yang ada. Sehingga dapat memudahkan perencana atau kontraktor untuk memiliki alternatif estimasi penjadwalan.

3. Hasil metode Monte Carlo dapat menjadi alternatif dalam merencanakan penjadwalan pekerjaan proyek, dikarenakan dengan mentode ini dapat memperkirakan besarnya probabilitas terlaksananya pekerjaan proyek sesuai dengan jadwal. Sehingga dapat merencanakan jadwal yang efisien dan mengurangi risiko yang mungkin terjadi pada pelaksanaan pekerjaan proyek.

\section{DAFTAR PUSTAKA (DAN PENULISAN PUSTAKA)}

Aulabih, Royyan. (2016). Penerapan Metode Monte Carlo pada Penjadwalan Proyek Gedung Dinas Sosial Kota Blitar. Skripsi.Malang: Jurusan Teknik Sipil Universitas Brawijaya.

Fadjar, A. (2008). Aplikasi Simulasi Monte Carlo dalam Estimasi Biaya Proyek. Jurnal SMARTek.6 (4):222-227. 
Filbert, Hans. (2017). Model Simulasi Prediksi Durasi Probabilistik Proyek Konstruksi Dengan Crystal Ball. Skripsi.Jakarta: Program Studi Teknik Sipil Universitas Tarumanagara.

Handoko, Swasono Widi. (2001). Pengukuran Reabilitas Durasi Proyek dan Penjadwalan Pelaksanaan Konstruksi dengan Pendekatan Statistika Program Evaluation and Review Technique (PERT) dan Monte Carlo Simulation (MCS).Tesis.Jakarta: Program Pascasarjana Universitas Indonesia.

Kumalasari, Aulia Indira. (2017). Alternatif Pemilihan Metode Penjadwalan dan Estimasi Biaya Proyek dengan Menggunakan Simulasi Monte Carlo Pada Pembangunan Gedung Neo Condotel Batu.Skripsi.Malang: Jurusan Teknik Sipil Universitas Muhammadiyah Malang.

Labombang, Matsura. (2011). Manajemen Risiko dalam Proyek Konstruksi. Jurnal SMARTek.Vol 9 No.1:39-46.

Shahtaheri, Maryam , Carl T. Haas dan Tabassom Salimi. (2016). A Stochastic Simulation Approach for the Integration of Risk and Uncertainty into Megaproject Cost and Schedule Estimates.JournalASCE Library.

Soeharto, I. (1998). Manajemen Proyek Dari Konseptual Sampai Operasional Jilid I, Penerbit PT. Gelora Aksara Pratama, Jakarta.

Suardika, I. Nyoman dan I Wayan Darya Suparta. (2017). Aplikasi Simulasi Monte Carlo untuk Penjadwalan Proyek Konstruksi Menggunakan Microsoft Project.Jurnal Prosiding Sentrinov.Vol. 3 
